\title{
Securing tropical forest carbon: the contribution of protected areas to REDD
}

\author{
Jörn P. W. Scharlemann, Valerie Kapos, Alis on Campbell \\ Igor Lysenko, Neil D. Burgess, Matthew C. Hansen, Holly K. Gib b \\ BARNEY DICKSON and LERA MILES
}

\begin{abstract}
Forest loss and degradation in the tropics contribute $6-17 \%$ of all greenhouse gas emissions. Protected areas cover 217.2 million ha (19.6\%) of the world's humid tropical forests and contain c. 70.3 petagrams of carbon $(\mathrm{Pg} \mathrm{C})$ in biomass and soil to $1 \mathrm{~m}$ depth. Between 2000 and 2005, we estimate that 1.75 million ha of forest were lost from protected areas in humid tropical forests, causing the emission of $0.25-0.33$ Pg C. Protected areas lost about half as much carbon as the same area of unprotected forest. We estimate that the reduction of these carbon emissions from ongoing deforestation in protected sites in humid tropical forests could be valued at USD 6,200-7,400 million depending on the land use after clearance. This is $>1.5$ times the estimated spending on protected area management in these regions. Improving management of protected areas to retain forest cover better may be an important, although certainly not sufficient, component of an overall strategy for reducing emissions from deforestation and forest degradation (REDD).
\end{abstract}

Keywords Carbon storage, deforestation, protected areas, REDD

\section{Introduction}

T and-use change, primarily through tropical forest loss $\checkmark$ and degradation, is estimated to contribute $6-17 \%$ of all anthropogenic greenhouse gas emissions (van der Werf et al., 2009), equivalent to $5.5 \pm 2.6$ petagrams $(\mathrm{Pg})$ of carbon dioxide $\left(\mathrm{CO}_{2}\right)$ per year (Le Quéré et al., 2009). There is broad scientific and political consensus that $\mathrm{CO}_{2}$

Jörn P. W. SChaRlemann (Corresponding author), VALERIE Kapos*, Alison Campbell, Igor Lysenko, Neil D. Burgess ${ }^{\dagger}$, Barney Dickson and Lera Miles United Nations Environment Programme World Conservation Monitoring Centre, 219 Huntingdon Road, Cambridge, CB3 0DL, UK. E-mail jorn.scharlemann@unep-wcmc.org

Matthew C. Hansen Geographic Information Science Center of Excellence, South Dakota State University, Brookings, USA

Holly K. Gibbs Program on Food Security and the Environment, Stanford University, Stanford, USA

*Also at: Department of Zoology, University of Cambridge, Cambridge, UK

${ }^{\dagger}$ Also at: WWF-US, Washington, DC, USA, and Department of Biology, University of Copenhagen, Copenhagen, Denmark

Received 14 December 2009. Revision requested 8 February 2010.

Accepted 26 March 2010. emissions from land-use change, particularly clearance and degradation of forests in developing countries, must be reduced urgently. The Copenhagen Accord (UNFCCC, 2009), one of the outcomes of the United Nations Framework Convention on Climate Change conference in December 2009, expressed strong support for a mechanism whereby developed countries provide financial incentives to developing countries for reducing emissions from deforestation and forest degradation (REDD) and enhancing sequestration by forests.

Legal protection is one land management tool that could slow forest carbon loss. Protected areas cover c. $12 \%$ of the terrestrial surface (Coad et al., 2009). Several studies have shown that protected areas can be effective at reducing deforestation: for example, analyses that compared deforestation inside and outside protected areas (DeFries et al., 2005; Nepstad et al., 2006; Joppa et al., 2008) and that matched protected areas with unprotected locations to control for other characteristics that may also affect deforestation (Andam et al., 2008; Pfaff et al., 2009). These analyses focused on regional or countrywide subsets of protected areas. However, to assess the role of existing protected areas in REDD, a comprehensive assessment of their potential to secure forest carbon is needed.

Here, we combine up-to-date, spatially explicit data for the humid tropics on carbon stocks within biomass (Ruesch \& Gibbs, 2008) and soil (Global Soil Data Task Group, 2000), the network of protected areas (UNEP-WCMC \& IUCN, 2007), and deforestation from 2000 to 2005 (Hansen et al., 2008), to estimate: (1) carbon contained within protected areas in the humid tropics that had been established by 2000 , (2) loss of humid tropical forest within protected areas, (3) total carbon released by clearance of humid tropical forest inside and outside protected areas under four scenarios of land use following forest clearance, and (4) the economic potential of avoided carbon emissions from forest clearance.

\section{Methods}

The humid tropical forest biome was delineated as all WWF ecoregions containing humid tropical forests (Olson et al., 2001; Fig. 1). All analyses were performed in ArcGIS v. 9.2 (ESRI, Redlands, USA) in MODerate resolution Imaging Spectroradiometer (MODIS) sinusoidal projection.

The analyses included 'protected sites' from the World Database of Protected Areas (UNEP-WCMC \& IUCN, 

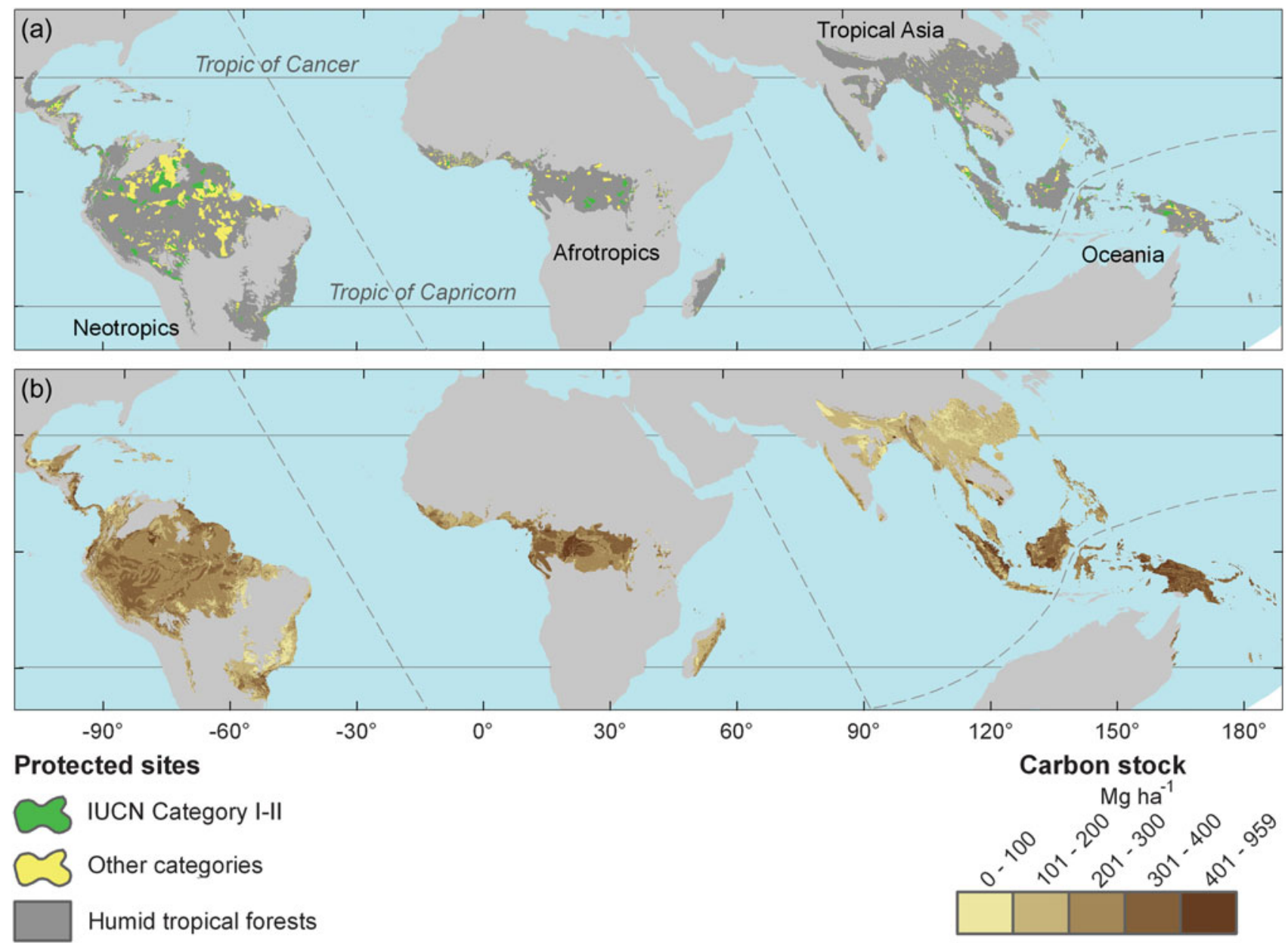

FIG. 1 (a) Location of protected sites (UNEP-WCMC \& IUCN, 2007) by IUCN management category, and (b) total carbon stock in above and below ground biomass (Ruesch \& Gibbs, 2008) and soil to $1 \mathrm{~m}$ depth (Global Soil Data Task Group, 2000) in the humid tropical forest biome. Dashed lines show separation between the four humid tropical forest regions used in these analyses, which were performed in MODerate resolution Imaging Spectroradiometer sinusoidal projection at a resolution of $500 \mathrm{~m}$.

2007). These were defined as national and international protected areas with spatial boundary information, located inside the humid tropical forest biome. To avoid including protected areas established during the period of deforestation analysis, we excluded those designated after 1999. In total, the data analysed included 5,787 protected sites. Data were analysed separately for protected sites with more restrictive land management regimes (those assigned IUCN management Categories I and II; IUCN, 1994) and all other protected sites (with IUCN Categories III-VI and those lacking an assigned management category; Fig. 1a).

A data set of total carbon stock (Fig. 1b) in terrestrial ecosystems within the humid tropical forest biome was prepared by combining spatially explicit data sets for biomass carbon (Ruesch \& Gibbs, 2008), produced by applying the Intergovernmental Panel on Climate Change (IPCC) Tier-1 methodology to a satellite-derived land cover map, and organic soil carbon stock to $1 \mathrm{~m}$ depth (Global Soil Data Task Group, 2000).

Forest area for 2000 was derived from $500 \mathrm{~m}$ resolution MODIS Vegetation Continuous Field tree cover data
(Hansen et al., 2003, 2006). We converted these data to percentage forest cover by dividing by 0.8 , as the data represent tree canopy cover (maximum recorded Vegetation Continuous Field canopy cover is $80 \%$; Hansen et al., 2003), and removed pixels with $<25 \%$ forest cover to exclude nonforested pixels with some canopy cover (such as shrublands). Forest area is percentage forest cover multiplied by pixel area. Gross forest area loss between 2000 and 2005 was calculated by multiplying the forest area and change probability (Hansen et al., 2008) within each pixel.

We explored four illustrative scenarios of carbon loss that only differed in how the land might be used after deforestation (Table 2): (1) biomass blitz, forest clearance removes all biomass carbon but soil carbon remains unchanged; (2) pasturelands, cleared areas converted to pasture globally; (3) oil palm pastureland, cleared areas converted to pasture in Neotropics and Afrotropics and to oil palm plantations in Tropical Asia and Oceania; (4) oil palm cropland, cleared areas converted to arable crops in Neotropics and Afrotropics and to oil palm in Tropical Asia and Oceania. For these scenarios carbon loss was estimated 
TABLE 1 Observed forest area in 2000 derived from MODerate Resolution Imaging Spectroradiometer Vegetation Continuous Field data (Hansen et al., 2006), total carbon stocks in biomass (Ruesch \& Gibbs, 2008) and soil (Global Soil Data Task Group, 2000) in 2000, and observed forest area loss between 2000 and 2005 (Hansen et al., 2008) inside protected sites and overall in four regions of the humid tropical forest biome.

\begin{tabular}{|c|c|c|c|c|c|}
\hline & Neotropics & Afrotropics & Tropical Asia & Oceania & Total \\
\hline \multicolumn{6}{|l|}{ Forest area $\left(\mathrm{km}^{2}\right)$} \\
\hline Total & $6,202,896$ & $1,857,518$ & $2,209,638$ & 807,747 & $11,077,799$ \\
\hline In protected sites & $1,567,022$ & 226,974 & 281,855 & 96,163 & $2,172,014$ \\
\hline$\%$ of total & 25.3 & 12.2 & 12.8 & 11.9 & 19.6 \\
\hline \multicolumn{6}{|c|}{ Carbon stock (Pg C } \\
\hline Total & 197.8 & 67.0 & 78.7 & 37.7 & 381.1 \\
\hline In protected sites & 48.4 & 7.7 & 9.3 & 4.9 & 70.3 \\
\hline$\%$ of total & 24.5 & 11.6 & 11.8 & 13.0 & 18.5 \\
\hline \multicolumn{6}{|l|}{ Forest area loss $\left(\mathrm{km}^{2}\right)$} \\
\hline Total & 148,448 & 4,442 & 47,920 & 6,560 & 207,369 \\
\hline In protected sites & 12,396 & 705 & 3,757 & 641 & 17,499 \\
\hline$\%$ loss of forest area & 0.79 & 0.31 & 1.33 & 0.67 & 0.81 \\
\hline
\end{tabular}

by assuming that all forest biomass carbon (Ruesch \& Gibbs, 2008) is emitted to the atmosphere as $\mathrm{CO}_{2}$ over the long term and that soil and biomass carbon values for the new land use are as in Table 2. In some areas, particularly in Tropical Asia and Oceania, there was a clear discrepancy between the MODIS Vegetation Continuous Field and biomass carbon data, i.e. forest loss occurred in areas that did not have forestscale values of biomass carbon according to the biomass carbon data. For these pixels, which totalled 183.7 million ha or $8.9 \%$ of forest area loss, we substituted average regional forest carbon values for the biomass carbon data and used these as the basis for calculating carbon loss under the different land-use scenarios.

To estimate the financial value of reducing carbon loss from deforestation in protected sites we compiled data on market prices for forest carbon. Carbon prices vary among regions and projects, as well as over time, and thus any single value for carbon stored in forests should be considered notional, particularly given that the scale of the market will be strongly influenced by REDD implementation. Our review of forest carbon market prices and the voluntary carbon market suggests that the price of forest carbon is likely to be USD 1-15 per ton equivalent carbon dioxide ( $\mathrm{Mg} \mathrm{CO} \mathrm{CO}_{2}$; Campbell et al., 2008). To derive a notional economic value of the reduced carbon emissions we multiplied the estimated carbon loss from the four scenarios by an assumed mid-range market carbon price of USD 7.50 per $\mathrm{Mg} \mathrm{CO}_{2}$ e. We compared this value to the best available information on the cost of protected area management. Using data from James et al. (2001) we estimated spending on management of all protected areas (including those without forest) in four tropical developing regions containing humid tropical forests in 1996 as USD 601

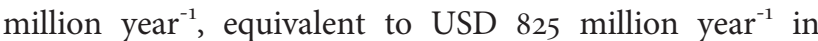
2008. Over 5 years, spending on management may have been as much as USD 4,125 million.

\section{Results}

In 2000 , existing protected sites covered $19.6 \%$ of humid tropical forests (217.2 million ha) and contained 18.5\% (70.3 Pg $C_{\text {biomass }+ \text { soil }}$ of the biomass and soil carbon within that habitat, representing $3.5 \%$ of global terrestrial carbon stocks (Table 1). The largest carbon stock within protected sites was in the Neotropics (48.4 Pg C biomass + soil or $24.5 \%$ of total regional carbon stock), where its large forest extent held more than double (2.5-5.2 times) the carbon stock of any other tropical region (Fig. 2a). Protected sites in each of the other humid tropical regions held $<10$ Pg $\mathrm{C}_{\text {biomass + soil }}$, representing $11.6-13.0 \%$ of total regional carbon stocks (Table 1).

Despite their legal status protected sites in the humid tropics were estimated to have lost 1.75 million ha of forest cover between 2000 and 2005. Regionally, total deforestation within protected sites was greatest in the Neotropics (1.24 million ha or $70.8 \%$ of total deforestation inside protected sites) but protected sites in tropical Asia lost the greatest percentage of their forest cover $(1.33 \%$ vs $0.79 \%$ in the Neotropics).

Globally, the forest cleared within protected sites from 2000 to 2005 represented $0.27 \mathrm{Pg} \mathrm{C}_{\text {biomass }}$ or $0.65 \%$ of their biomass carbon stock. Depending on land use after deforestation (pasture, arable crops or oil palm) and potential carbon loss from soils, forest clearance within protected sites resulted in estimated total emissions of $0.22-0.27 \mathrm{Pg} \mathrm{C}$ or $8.8-8.9 \%$ of the carbon emitted by all deforestation in the humid tropics during the same period (2.56-3.08 Pg C). The most carbon was released by deforestation in Neotropical protected sites, which lost $0.19-0.23 \mathrm{Pg}$ C. The greatest proportion of carbon stocks lost from protected sites occurred in Tropical Asia and Oceania (Fig. 2b; Table 2).

From 2000 to 2005 proportional carbon loss from humid tropical forests within protected sites was about 
TABLE 2 Four scenarios of carbon loss across four regions in the humid tropical forests in protected sites. The biomass carbon stock and soil carbon loss for each of the land uses in the scenarios are based on data from Gibbs et al. (2008).

\begin{tabular}{|c|c|c|c|c|c|}
\hline & Neotropics & Afrotropics & Tropical Asia & Oceania & Total \\
\hline \multicolumn{6}{|l|}{ Biomass blitz $^{1}$} \\
\hline Biomass $\left(\mathrm{Mg} \mathrm{C} \mathrm{ha}^{-1}\right)$ & 0 & 0 & 0 & 0 & 0 \\
\hline Soil $(\%$ original C) & 100 & 100 & 100 & 100 & 100 \\
\hline \multicolumn{6}{|l|}{ Carbon loss } \\
\hline Total $(\operatorname{Pg} \mathrm{C})$ & 2.27 & 0.07 & 0.62 & 0.12 & 3.08 \\
\hline In protected sites $(\mathrm{Pg} C)$ & 0.20 & 0.01 & 0.04 & 0.01 & 0.27 \\
\hline$\%$ of total C stock & 0.42 & 0.15 & 0.47 & 0.26 & 0.38 \\
\hline \multicolumn{6}{|l|}{ Pasturelands ${ }^{2}$} \\
\hline Biomass $\left(\mathrm{Mg} \mathrm{C} \mathrm{ha}^{-1}\right)$ & 8 & 8 & 8 & 8 & 8 \\
\hline Soil $(\%$ original C) & 100 & 100 & 100 & 100 & 100 \\
\hline \multicolumn{6}{|l|}{ Carbon loss } \\
\hline Total $(\operatorname{Pg~C})$ & 2.15 & 0.06 & 0.58 & 0.12 & 2.92 \\
\hline In protected sites $(\mathrm{Pg} C)$ & 0.19 & 0.01 & 0.04 & 0.01 & 0.26 \\
\hline$\%$ of total C stock & 0.40 & 0.14 & 0.43 & 0.25 & 0.36 \\
\hline \multicolumn{6}{|l|}{ Oil palm pastureland ${ }^{3}$} \\
\hline Biomass $\left(\mathrm{Mg} \mathrm{C} \mathrm{ha}^{-1}\right)$ & 8 & 8 & 88 & 88 & $8 / 88$ \\
\hline Soil (\% original C) & 100 & 100 & 90 & 90 & $100 / 90$ \\
\hline \multicolumn{6}{|l|}{ Carbon loss } \\
\hline Total $(\operatorname{Pg~C})$ & 2.15 & 0.06 & 0.25 & 0.09 & 2.56 \\
\hline In protected sites $(\mathrm{Pg} \mathrm{C})$ & 0.19 & 0.01 & 0.01 & 0.01 & 0.22 \\
\hline$\%$ of total C stock & 0.40 & 0.14 & 0.11 & 0.20 & 0.32 \\
\hline \multicolumn{6}{|l|}{ Oil palm cropland ${ }^{4}$} \\
\hline Biomass $\left(\mathrm{Mg} \mathrm{C} \mathrm{ha}^{-1}\right)$ & 6 & 4 & 88 & 88 & $6 / 4 / 88$ \\
\hline Soil $(\%$ original C) & 75 & 75 & 90 & 90 & $75 / 75 / 90$ \\
\hline \multicolumn{6}{|l|}{ Carbon loss } \\
\hline Total $(\operatorname{Pg} \mathrm{C})$ & 2.52 & 0.08 & 0.25 & 0.09 & 2.95 \\
\hline In protected sites $(\mathrm{Pg} \mathrm{C})$ & 0.23 & 0.01 & 0.01 & 0.01 & 0.26 \\
\hline$\%$ of total C stock & 0.47 & 0.17 & 0.11 & 0.20 & 0.37 \\
\hline
\end{tabular}

${ }^{1}$ Forest clearance removes all biomass carbon but soil carbon remains unchanged

${ }^{2}$ Cleared areas converted to pasture

${ }^{3}$ Cleared areas converted to pasture in Neotropics and Afrotropics and to oil palm plantations in Tropical Asia and Oceania

${ }^{4}$ Cleared areas converted to arable crops in Neotropics and Afrotropics and to oil palm in Tropical Asia and Oceania

half that from humid tropical forests outside protected sites (Fig. 2b). Furthermore, proportional carbon loss from protected sites with more restrictive management (IUCN management Categories I and II), which cover $6.1 \%$ of humid tropical forest area (67.9 million ha) and contain $5.7 \%$ (21.8 Pg $\mathrm{C}_{\text {biomass }+ \text { soil }}$ ) of the carbon, was about one third that from unprotected forests (depending on scenario; Fig. 2c). All other protected sites (IUCN management Categories III-VI and non-assigned) covered 13.5\% (149.3 million ha) of the biome, contained $12.7 \%$ (48.5 $\mathrm{Pg} \mathrm{C}_{\text {biomass + }}$ soil) of the carbon and lost $0.37-0.44 \%$ (0.18-0.22 Pg C). The unprotected forests covered $80.4 \%$ ( 890.6 million ha) of the biome, contained $81.5 \%$ (310.7 Pg $\mathrm{C}_{\text {biomass }}+$ soil $)$ of the carbon and lost $0.67-0.87 \%$ (2.56-3.08 Pg C).

Based on the observed forest loss and assuming a notional market carbon price of USD 7.50 per $\mathrm{Mg} \mathrm{CO}_{2}$ e, we estimate that reducing the carbon emissions from deforestation in protected sites in the humid tropics could be valued at USD $6,200-7,400$ million depending on the land-use scenario used. This is $1.5-1.8$ times the estimated spending on protected area management in these regions.

\section{Discussion}

Existing protected sites in humid tropical forests contain c. $20 \%$ of all carbon in this biome and retained more of their carbon than other land management regimes (Fig. 2c). Their protected status may be one factor, amongst others such as aspects of remoteness (Nelson \& Chomitz, 2009), contributing to their lower deforestation rates. Nonetheless, protected sites still lost substantial amounts of carbon from deforestation within their boundaries.

The estimates based on MODIS imagery are likely to be conservative estimates of deforestation and associated carbon loss. This is partially because of the relatively coarse spatial resolution of MODIS data, which are likely to miss small-scale deforestation and forest degradation. Our deforestation estimate of 4.1 million ha year ${ }^{-1}$ across the humid tropical forests from 2000 to 2005 is similar to the 5.8 million ha year ${ }^{-1}$ estimated using higher resolution Landsat data from 1990 to 1997 (Achard et al., 2002), but substantially lower than the 12.9 million ha year ${ }^{-1}$ reported across all forests (FAO, 2006). Our estimate of carbon emission of 

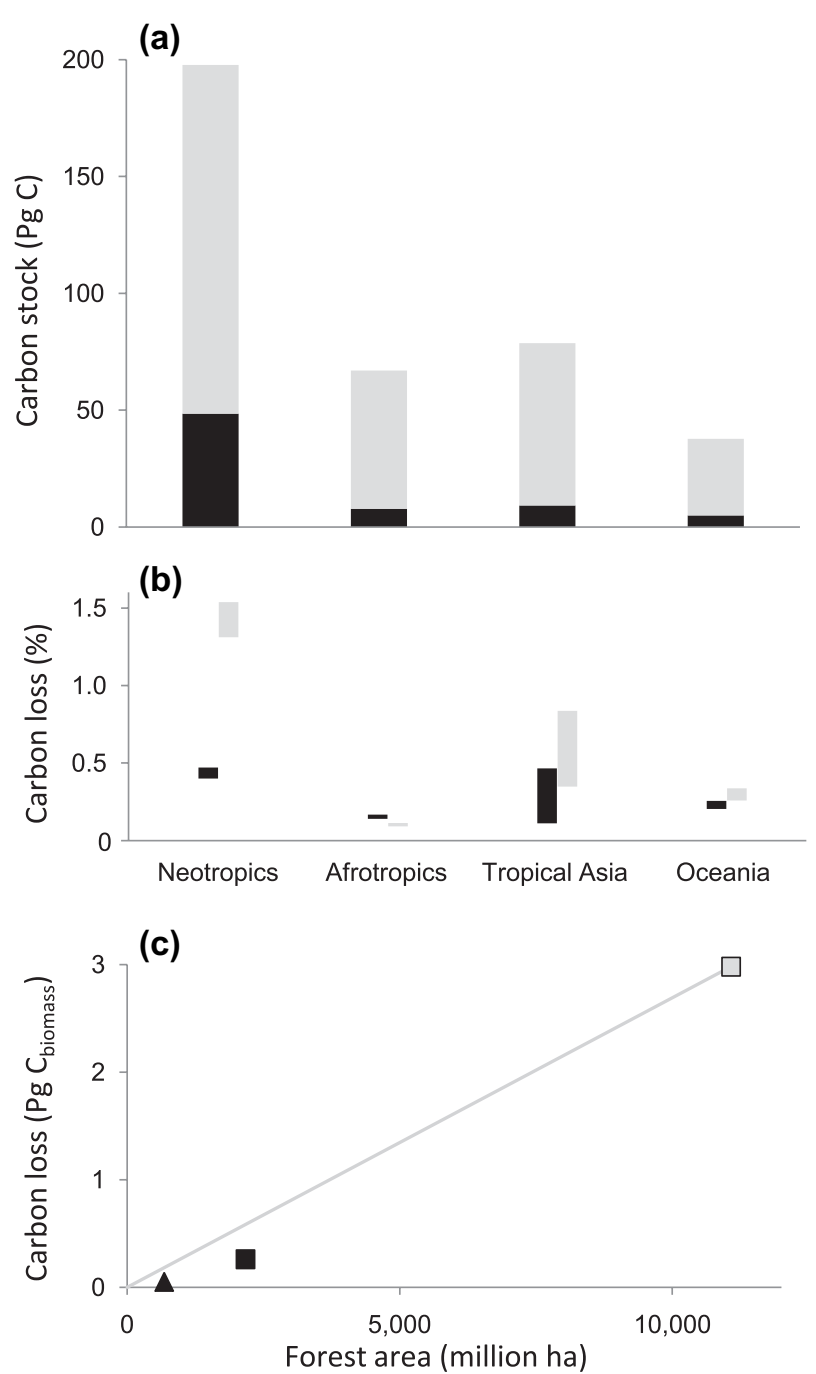

FIG. 2 (a) Total carbon stock in biomass and soil in humid tropical forests inside (black) and outside (grey) protected sites by region (Fig. 1). (b) Range of biomass and soil carbon loss (in percent of total carbon stock) resulting from deforestation in 2000-2005 inside (black) and outside (grey) protected sites according to four land-use scenarios (see Methods for details). (c) Biomass carbon loss vs forest area for protected sites in IUCN management Categories I-II (black triangle) and III-VI or no IUCN category (black square) and unprotected humid tropical forests (grey square). The line indicates proportional carbon loss in humid tropical forests overall. Protected sites lost substantially less carbon relative to their total area than humid tropical forests overall but represented a small fraction of both carbon loss and forest area.

0.51-0.62 Pg C year ${ }^{-1}$ across the humid tropics falls within the range of carbon emission estimated from satellite data for the 1990s (mean $=0.9$ Pg C year ${ }^{-1}$, range 0.5-1.4; DeFries et al., 2002), but is lower than the $1.1 \pm 95 \%$ CI $0.3 \mathrm{Pg} \mathrm{C}$ year $^{-1}$ or 1.2 Pg C year ${ }^{-1}$ estimated for tropical deforestation and degradation (Achard et al., 2004; van der Werf et al., 2009). The biomass carbon stock estimates (Ruesch \& Gibbs, 2008), which are based on the IPCC Tier-1 methodology that relies on relatively old data from a small sample of trees, mask local variation resulting from natural disturbance, topography, microclimate and soil type (Gibbs et al., 2007; Keith et al., 2009). Therefore, we may have over- or underestimated carbon loss at any given location. Furthermore, knowledge of soil carbon stocks is relatively uncertain (Guo \& Gifford, 2002; Ramankutty et al., 2007). Collection of new data is required to improve carbon stock estimates in biomass and soil.

Despite these discrepancies in forest clearance and carbon loss statistics, the MODIS data are the only spatially explicit deforestation data currently available that cover an entire biome. Intersecting protected area boundaries with coarse resolution remote sensing data adds some uncertainty to our estimates of deforestation and carbon loss. Furthermore, it is likely that additional carbon was lost from protected areas not included in these analyses, i.e. those established after 1999.

We estimate that reducing the carbon emissions from deforestation in protected sites in the humid tropics could be valued at USD 6,200-7,400 million depending on the land-use scenario used. This is $>1.5$ times the estimated spending on protected area management in these regions (James et al., 2001). Directing even a fraction of the value of their carbon losses to improving protected area management could both help secure forest carbon and generate large co-benefits in terms of biodiversity protection (Miles \& Kapos, 2008; Ricketts et al., 2010) and the delivery of other ecosystem services.

In conclusion, protected sites lost substantially less carbon relative to their total area than humid tropical forests overall but represented a small fraction of both carbon loss and forest area. Improving management of protected areas to increase their effectiveness at retaining forest cover may be an important, although certainly not sufficient, component of an overall strategy to reduce emissions from deforestation and forest degradation.

\section{Acknowledgements}

We thank the protected areas team at UNEP-WCMC for support and Jeremy Niven, Taylor Ricketts and two anonymous reviewers for helpful comments. The Federal Ministry for the Environment, Nature Conservation and Nuclear Safety (Germany) and The Nature Conservancy (USA) provided financial support.

\section{References}

Achard, F., Eva, H.D., Mayaux, P., Stibig, H.J. \& Belward, A. (2004) Improved estimates of net carbon emissions from land cover change in the tropics for the 1990s. Global Biogeochemical Cycles, 18, GB2008.

Achard, F., Eva, H.D., Stibig, H.J., Mayaux, P., Gallego, J., Richards, T. et al. (2002) Determination of deforestation rates of the world's humid tropical forests. Science, 297, 999-1002. 
Andam, K.S., Ferraro, P.J., Pfaff, A., Sanchez-Azofeifa, G.A. \& Robalino, J.A. (2008) Measuring the effectiveness of protected area networks in reducing deforestation. Proceedings of the National Academy of Sciences of the USA, 105, 16089-16094.

Campbell, A., Kapos, V., Lysenko, I., Scharlemann, J.P.W., Dickson, B., Gibis, H.K. et al. (2008) Carbon Emissions from Forest Loss in Protected Areas. UNEP World Conservation Monitoring Centre, Cambridge, UK.

Coad, L., Burgess, N., Fish, L., Ravillious, C., Corrigan, C., Pavese, H. et al. (2009) Progress towards the Convention on Biological Diversity terrestrial 2010 and marine 2012 targets for protected area coverage. Parks, 17, 35-42.

DeFries, R., Hansen, A., Newton, A.C. \& Hansen, M.C. (2005) Increasing isolation of protected areas in tropical forests over the past twenty years. Ecological Applications, 15, 19-26.

DeFries, R.S., Houghton, R.A., Hansen, M.C., Field, C.B., Skole, D. \& Townshend, J. (2002) Carbon emissions from tropical deforestation and regrowth based on satellite observations for the 1980s and 1990s. Proceedings of the National Academy of Sciences of the USA, 99, 14256-14261.

FAO (Food and Agriculture Organization of the United Nations) (2006) Global Forest Resources Assessment 2005: Progress Towards Sustainable Forest Management. FAO, Rome, Italy.

Gibis, H.K., Brown, S., Niles, J.O. \& Foley, J.A. (2007) Monitoring and estimating tropical forest carbon stocks: making REDD a reality. Environmental Research Letters, 2, 045023.

Gibis, H.K., Johnston, M., Foley, J.A., Holloway, T., Monfreda, C., Ramankutty, N. et al. (2008) Carbon payback times for crop-based biofuel expansion in the tropics: the effects of changing yield and technology. Environmental Research Letters, 3, 034001.

Global Soll Data TASK Group (200o) Global Gridded Surfaces of Selected Soil Characteristics (IGBP-DIS). Oak Ridge National Laboratory Distributed Active Archive Center, Oak Ridge, USA. Http://www.daac.ornl.gov [accessed October 2009].

Guo, L.B. \& GifFord, R.M. (2002) Soil carbon stocks and land use change: a meta analysis. Global Change Biology, 8, 345-360.

Hansen, M.C., DeFries, R.S., Townshend, J.R., Carroll, M., DiMiceli, C. \& Sohlberg, R. (2003) Global percent tree cover at a spatial resolution of 500 meters: first results of the MODIS vegetation continuous fields algorithm. Earth Interact, 7, 1-15.

Hansen, M.C., DeFries, R.S., Townshend, J.R., Carroll, M., DiMiceli, C. \& Sohlberg, R. (2006) Vegetation Continuous Fields MOD44B, 2001 Percent Tree Cover, Collection 4. University of Maryland, College Park, USA.

Hansen, M.C., Stehman, S.V., Potapov, P.V., Loveland, T.R., Townshend, J.R.G., DeFries, R.S. et al. (2008) Humid tropical forest clearing from 2000 to 2005 quantified by using multitemporal and multiresolution remotely sensed data. Proceedings of the National Academy of Sciences of the USA, 105, 9439-9444.

IUCN (1994) Guidelines for Protected Area Management Categories. IUCN, Gland, Switzerland.

James, A., Gaston, K.J. \& Balmford, A. (2001) Can we afford to conserve biodiversity? BioScience, 51, 43-52.

Joppa, L.N., LoARie, S.R. \& Pimm, S.L. (2008) On the protection of "protected areas". Proceedings of the National Academy of Sciences of the USA, 105, 6673-6678.

Keith, H., Mackey, B.G. \& Lindenmayer, D.B. (2009) Reevaluation of forest biomass carbon stocks and lessons from the world's most carbon-dense forests. Proceedings of the National Academy of Sciences of the USA, 106, 11635-11640.

Le Quéré, C., Raupach, M.R., Canadell, J.G., Marland, G., Bopp, L., CiAis, P. et al. (2009) Trends in the sources and sinks of carbon dioxide. Nature Geoscience, 2, 831-836.
Miles, L. \& Kapos, V. (2008) Reducing greenhouse gas emissions from deforestation and forest degradation: global land-use implications. Science, 320, 1454-1455.

Nelson, A. \& Chomitz, K.M. (2009) Protected Area Effectiveness in Reducing Tropical Deforestation: A Global Analysis of the Impact of Protection Status. Independent Evaluation Group, Evaluation Brief 7. The World Bank, Washington, DC, USA.

Nepstad, D., Schwartzman, S., Bamberger, B., Santilli, M., Ray, D., SChlesinger, P. et al. (2006) Inhibition of Amazon deforestation and fire by parks and indigenous lands. Conservation Biology, 20, 65-73.

Olson, D.M., Dinerstein, E., Wikramanayake, E.D., Burgess, N.D., Powell, G.V.N., Underwood, E.C. et al. (2001) Terrestrial ecoregions of the world: a new map of life on Earth. BioScience, 51, 933-938.

Pfaff, A., Robalino, J., Sanchez-Azofeifa, G.A., Andam, K.S. \& FERRARO, P.J. (2009) Park location affects forest protection: land characteristics cause differences in park impacts across Costa Rica. B.E. Journal of Economic Analysis \& Policy, 9, article 5.

Ramankutty, N., Gibis, H.K., Achard, F., Defriess, R., Foley, J.A. \& Houghton, R.A. (2007) Challenges to estimating carbon emissions from tropical deforestation. Global Change Biology, 13, 51-66.

Ricketts, T.H., Soares - Filho, B., Da Fonseca, G.A.B., Nepstad, D., PfAFF, A., PETSONK, A. et al. (2010) Indigenous lands, protected areas, and slowing climate change. PLoS Biology, 8(3), e10o0331.

Ruesch, A.S. \& Gibis, H.K. (2008) New Global Biomass Carbon Map for the Year 2000 Based On IPCC Tier-1 Methodology. Carbon Dioxide Information Analysis Center, Oak Ridge National Laboratory, Oak Ridge, USA. Http://cdiac.ornl.gov [accessed October 2009].

UNEP-WCMC (United Nations Environment Programme-World Conservation Monitoring Centre) \& IUCN (2007) World Database on Protected Areas 2007. UNEP World Conservation Monitoring Centre, Cambridge UK and IUCN World Commission on Protected Areas, Gland, Switzerland.

UNFCCC (United Nations Framework Convention on Climate Change) (2009) Copenhagen Accord. FCCC/CP/2009/L.7. United Nations Framework Convention on Climate Change, Bonn, Germany. Http://unfccc.int/resource/docs/2009/cop15/eng/lo7.pdf [accessed February 2010].

van der Werf, G.R., Morton, D.C., DeFries, R.S., Olivier, J.G.J., Kasibhatla, P.S., Jackson, R.B. et al. (2009) $\mathrm{CO}_{2}$ emissions from forest loss. Nature Geoscience, 2, 737-738.

\section{Biographical sketches}

The authors represent a collaboration amongst seven organizations, ranging from academia to intergovernmental bodies, and a wide range of disciplines. JÖRN SCHARLEMANN is interested in analysing the impacts of long-term, large-scale changes of the environment using spatial analyses and GIS. VALERIE KAPOS is a forest ecologist and is currently involved in work on forest biodiversity conservation and climate change, including REDD. AlisON CAMPBELL is interested in natural resources policy. IGOR LYSENKO is a spatial analyst with strong interests in remote sensing and its applications. NEIL BURGESS specializes in the ecology and conservation of African ecosystems. MATTHEW HANSEN is a remote sensing scientist interested in large area land cover and land-use change mapping. Holly GibBs' research interests include tropical deforestation and agricultural expansion. BARNEY DICKSON is a specialist in climate change policy and its relation to biodiversity. LERA Miles' interests are in climate change impacts on biodiversity and the role of forests in climate mitigation. 